\title{
Personal account: Heinz Falk's contributions to geosciences
}

\author{
Klaus Wolkenstein ${ }^{1} \mathbb{D}$
}

Received: 23 December 2018 / Accepted: 8 January 2019 / Published online: 29 April 2019

(c) Springer-Verlag GmbH Austria, part of Springer Nature 2019

Heinz Falk is best known for his contributions to organic chemistry, but actually, his scientific interests are much broader and include geology/paleontology among other disciplines (Fig. 1).

During my diploma thesis (geology) on inorganic and organic pigments of fossils at the University of Heidelberg, I stumbled upon a paper of Heinz on color measurements of the pink Jurassic red alga Solenopora using simple diffuse reflectance UV-Vis spectroscopy, suggesting that the fossil pigments are organic compounds related to the so-called fringelite pigments (Fig. 2) [1]. The fringelites were discovered in fossil crinoids with distinct violet coloration from northern Switzerland and were described as hydroxylated phenanthroperylene quinones [2]. The work on the Solenopora pigments resulted from a cooperation with his friend Andreas E. Richter who asked him about the nature of the pigments causing the pink color of the fossils. A subsequent call in the journal "Fossilien", directed to the fossil collector community, to look for further colored fossils from different geological periods had a very good feedback and led to many further indications for the occurrence of these fossil pigments [3]. The results of the survey performed by his $\mathrm{PhD}$ student Elisabeth Mayr were also published in "Fossilien" [4]. To apply the method of color measurement to my samples, I phoned him and asked for a reference sample of a fossil crinoid containing fringelite pigments. He was very friendly, and soon, I received such a sample (that he also donated to me, Fig. 2, left).

In further studies on the fringelites, he looked for an explanation for the incredible stability of the fossil pigments that remained colorful after more than 150 million years. He found that fringelites can be stabilized by the formation of phenolates with bay hydroxy groups and the formation of peri chelate complexes [5]. Other studies on fossil material

Klaus Wolkenstein

klaus.wolkenstein@uni-goettingen.de

1 Department of Geobiology, Geoscience Centre, University of Göttingen, 37077 Göttingen, Germany included the chemical investigation of droplet inclusions in amber that turned out to be water droplets [6].

For my $\mathrm{PhD}$ thesis on the topic of phenanthroperylene quinone pigments in fossil crinoids, he provided support by sending an educt required for the synthesis of a polycyclic aromatic hydrocarbon that was needed as a reference compound [7]. However, even more important, he provided help by numerous constructive discussions on the chemistry of quinone pigments and during the preparation of a joint publication. An essential result of the work obtained by liquid chromatography, complementary mass spectrometry, and comparison to reference compounds was that the main pigment of fossil crinoids of Jurassic and Triassic age is fringelite $F(\mathbf{1})$ and a minor one is hypericin (2), the latter typically known from the medicinal plant St. John's wort (Hypericum perforatum). With the finding of hypericin and the reported discovery of related phenanthroperylene quinone pigments in a present-day crinoid (e.g., gymnochrome A, 3) [8], it was clear that the fossil pigments represent almost unchanged natural products that were biosynthesized millions of years ago $[9,10]$ (Scheme 1).

After several years with contact only by e-mails or phone, my first actual encounter with Heinz was in 2003 when I visited him at the Johannes Kepler University in Linz. After my PhD, Heinz suggested a postdoctoral stay in the group of his colleague Prof. Wolfgang Buchberger from the Institute of Analytical Chemistry, whose laboratory was equipped with modern LC-MS instrumentation. This was fortunately supported by Prof. Buchberger and a DFG grant. During my postdoc time at the University of Linz, I had the opportunity to investigate the Solenopora pigments in detail while being mentored by Heinz. One day, we received the first high-resolution mass spectra from Dr. Jürgen H. Gross, a former colleague from the University of Heidelberg, who concluded from the isotopic pattern that the fossil pigments contain the element boron. This was a huge surprise for all of us, since boron is only rarely found in natural products and has never before been reported from a fossil organic compound. Now, it was also obvious that the Solenopora pigments were different to the 


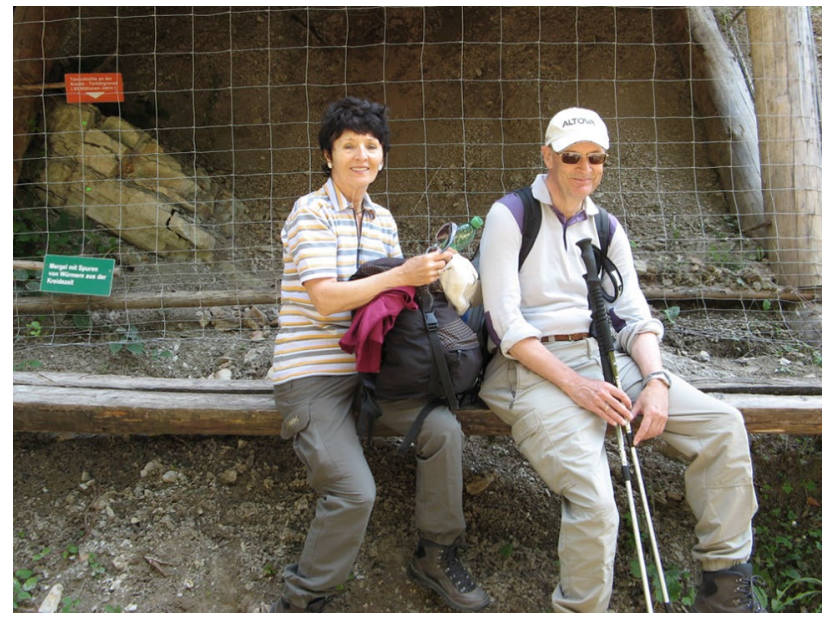

Fig. 1 Professor Heinz Falk and his wife Rotraud at the K/T (Cretaceous/Tertiary) boundary of Gams near Hieflau, Steiermark, Austria, in April 2007

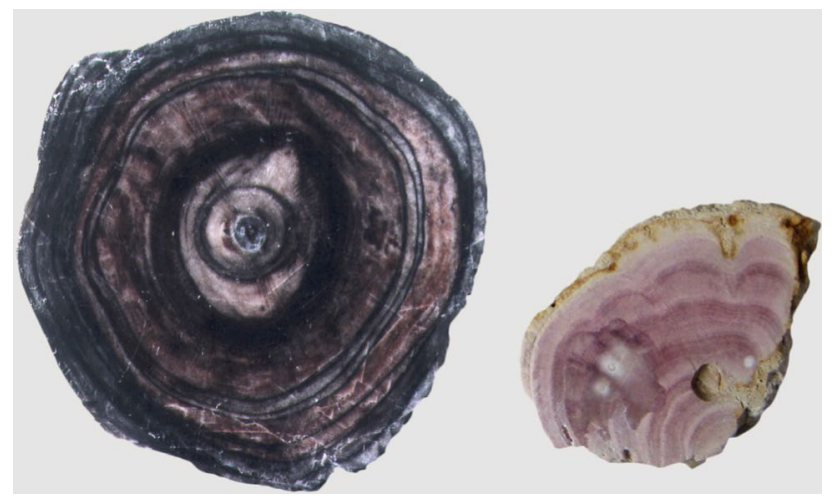

Fig. 2 Fossils with exceptional preservation of organic pigments. Cross section of the Jurassic crinoid Liliocrinus munsterianus from Switzerland colored by fringelite pigments (left) and cross section of the Jurassic red alga Solenopora jurassica from France colored by borolithochromes (right), both fossils are in the same scale, diameter of the crinoid section approximately $5 \mathrm{~cm}$

fringelites. Further degradation experiments and measurements of circular dichroism indicated that we discovered a new class of fossil organic pigments, the so-called borolithochromes. The pigments were characterized as complicated spiroborates with two phenolic moieties as boron ligands [11]. However, no NMR could be applied because of the tiny amounts of the individual pigments. Only within a further postdoctoral project, the structure of the borolithochromes was fully elucidated, based on "larger amounts" (up to $50 \mu \mathrm{g}$ ) of isolated pigments and using microcryoprobe NMR, revealing the extremely unusual benzo $[g h]$ tetraphene carbon skeleton of the boron ligands (e.g., borolithochrome $\mathrm{C} 1,4$ ) [12]. The only other natural products with this carbon skeleton are the clostrubins (e.g.,

\section{Scheme 1}<smiles></smiles>

1: $\mathrm{R}^{1}=\mathrm{R}^{2}=\mathrm{H}$

2: $R^{1}=R^{2}=\mathrm{CH}_{3}$

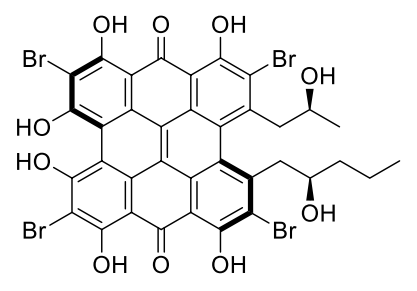

3

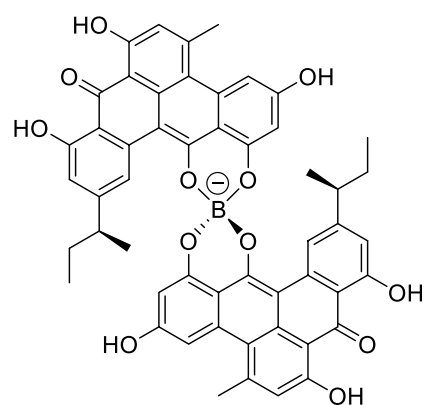

4<smiles>CC(=O)c1ccc2c(O)c(O)c3c4cc(C)cc(O)c4c(=O)c4c(O)cc(C)c(c14)c23</smiles>

clostrubin A, 5) that have only recently been discovered in present-day Clostridium bacteria [13].

In 2011, Heinz wrote a short overview on organic compounds in rocks representing traces of life that led to the much more comprehensive review "Natural Product Molecular Fossils" [14, 15]. This is not a comprehensive listing of all of Heinz's contributions to geosciences. In recent years, Heinz also wrote numerous reports about new exhibitions in the Vienna Natural History Museum, the Oberösterreichisches Landesmuseum in Linz, and other museums, which he published in "Fossilien", and since 2012, in the online journal "Leitfossil.de".

Heinz is a mentor and friend for me. I thank him for his countless "chemical advices" and recommendation from his long experience as editor of Monatshefte für Chemie during the preparation of many manuscripts. Heinz Falk's contributions in geosciences are very important, because they are truly interdisciplinary, viewing geological phenomena in the light of organic chemistry. He has the ability to explain complicated chemical topics to those who may usually shy away from structural formulas that are typically used in chemistry. His aim is to build a bridge between the disciplines by reporting these interdisciplinary results to both, the chemical community and the paleontological community including fossil collectors and the general public.

\section{References}

1. Falk H, Mayr E, Richter AE (1994) Mikrochim Acta 117:1

2. Blumer M (1960) Nature 188:1100

3. Richter AE (1995) Fossilien 12:327

4. Falk H (1997) Fossilien 14:89

5. Falk H, Mayr E (1997) Monatsh Chem 128:353 
6. Buchberger W, Falk H, Katzmayr MU, Richter AE (1997) Monatsh Chem 128:177

7. Wolkenstein K, Gross JH, Oeser T, Schöler HF (2002) Tetrahedron Lett 43:1653

8. De Riccardis F, Iorizzi M, Minale L, Riccio R, Richer de Forges B, Debitus C (1991) J Org Chem 56:6781

9. Wolkenstein K, Gross JH, Falk H, Schöler HF (2006) Proc R Soc B Biol Sci 273:451

10. Wolkenstein K, Falk H (2006) Fossilien 23:268
11. Wolkenstein K, Gross JH, Falk H (2010) Proc Natl Acad Sci USA 107:19374

12. Wolkenstein K, Sun H, Falk H, Griesinger C (2015) J Am Chem Soc 137:13460

13. Pidot S, Ishida K, Cyrulies M, Hertweck C (2014) Angew Chem Int Ed 53:7856

14. Falk H, Wolkenstein K (2011) Nachr Chem 59:517

15. Falk H, Wolkenstein K (2017) Prog Chem Org Nat Prod 104:1 